\title{
Microencapsulating and Banking Living Cells for Cell-Based Medicine
}

\author{
Wujie Zhang ${ }^{1,2}$ and Xiaoming $\mathrm{He}^{1,2,3, *}$ \\ ${ }^{1}$ Department of Biomedical Engineering, \\ ${ }^{2}$ Davis Heart and Lung Research Institute, and \\ ${ }^{3}$ James Comprehensive Cancer Center \\ The Ohio State University \\ Columbus, $\mathrm{OH} 43210$
}

Submitted March 2011. Accepted for publication August 2011.

\begin{abstract}
A major challenge to the eventual success of the emerging cell-based medicine such as tissue engineering, regenerative medicine, and cell transplantation is the limited availability of the desired cell sources. This challenge can be addressed by cell microencapsulation to overcome the undesired immune response (i.e., to achieve immunoisolation) so that non-autologous cells can be used to treat human diseases, and by cell/tissue preservation to bank living cells for wide distribution to end users so that they are readily available when needed in the future. This review summarizes the status quo of research in both cell microencapsulation and banking the microencapsulated cells. It is concluded with a brief outlook of future research directions in this important field.
\end{abstract}

Keywords: microencapsulation, cryopreservation, vitrification, cytotherapy, gene therapy, transplantation

\section{INTRODUCTION}

A major challenge to the emerging cell-based medicine for the treatment of diseases is the host immune rejection of the transplanted donor cells or engineered tissue [1 - 10]. One way to address this problem is to use drugs to achieve immunosuppression. However, suppressing the patient's immune system may put the patient at risk for many other diseases. An alternative is to encapsulate living cells in small microcapsules to achieve immunoisolation of the cells (see Figure 1) so that they can survive well in the patient's body after transplantation [1 - 10]. The microcapsule's membrane protects the encapsulated cells from being damaged by both the host's immune system and mechanical stresses while allowing free diffusion of nutrients and metabolic wastes for the cells to survive. Moreover, the membrane could be designed to achieve

*Corresponding author: Xiaoming He, Department of Biomedical Engineering, The Ohio State University, 1080 Carmack Road, Columbus, OH 43210. Phone: (614) 292-6992. Fax: (614) 292-7301. Email: he.429@osu.edu. 
controlled/sustained release of therapeutic product produced by the encapsulated cells to treat a variety of diseases including diabetes, liver failure, as well as neurodegenerative, musculoskeletal, and cardiovascular diseases [1 - 10].

In this review, the materials and/or methods used for microencapsulating a variety of cells and banking (by cryopreservation) the microencapsulated cells for future use are summarized. The latter is an enabling technology for the eventual success of cell-based medicine because cell-based commercial products must be banked for wide distribution to end users (e.g., hospitals and medical centers). This review concludes with a brief outlook of future directions in this important field.

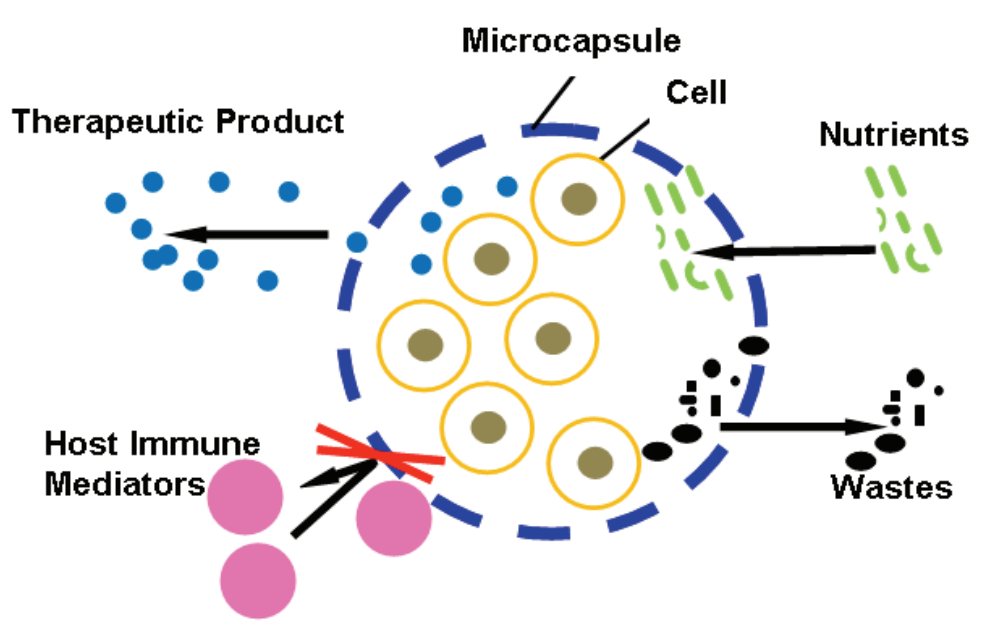

Figure 1. A schematic illustration of the concept of immunoisolation by encapsulating living cells in microcapsules that have a semipermeable wall to allow free diffusion of nutrients, metabolic wastes, and therapeutic agents while blocking any host immune mediators from getting in contact with the encapsulated cells.

\section{MATERIALS AND METHODS FOR MICROENCAPSULATION OF MAM- MALIAN CELLS}

\subsection{Materials for Cell Microencapsulation}

A variety of natural and synthetic polymers (Table 1) have been used for cell microencapsulation, including alginate, poly(ethylene glycol) (PEG), chitosan, collagen, dextran, poly(vinyl alcohol) (PVA), agarose (with or without gelatin), hyaluronic acid (HA), 2-hydroxyethyl methacrylate (HEMA), poly(lactic-co-glycolic acid) (PLGA) [3 - 6, 11 - 13]. In general, natural materials are biodegradable and might have a better biocompatibility, while synthetic materials have more consistent compositions [11]. Among these materials, alginate is most widely used for cell microencapsulation due to its natural origin (e.g., brown seaweeds) and excellent biocompatibility [3 - 5]. Alginates are linear block polymers consisting of $\alpha-\mathrm{L}-$ 
guluronic acid (G block) and $\beta$-D-manuronic acid (M block). The gelation of alginate in divalent cations is a result of the formation of the calcium junctions of GG-GG, MGGG and MG-MG between alginate molecules. The $\mathrm{G}$ and $\mathrm{M}$ contents vary with alginate sources and can affect the gel properties including the mechanical strength, biocompatibility and permeability [14, 15]. Moreover, other divalent cations, such as $\mathrm{Ba}^{2+}$ and $\mathrm{Sr}^{2+}$, have been used for microencapsulation. The gel properties are shown to be dependent on the cross-linking ion (due to different affinity to alginate) used, ion concentration, and time for gelation [16, 17]. Interestingly, stable, homogeneous alginate microcapsules can be produced by injecting $\mathrm{BaCl}_{2}$ crystals into the microcapsule core using the crystal gun technique before their contact with external $\mathrm{Ba}^{2+}$. On the contrary, inhomogeneous capsule has been designed by combining high $\mathrm{G}$ content alginate with $\mathrm{Ca}^{2+}$ and $\mathrm{Ba}^{2+}$ [17]. This inhomogeneous system is shown to have high stability and allow for long-term in vivo function of human islet graft [18]. Many studies show that purified sodium alginate (after removal of visible aggregates, proteins and endotoxin content) could improve the biocompatibility and mechanical strength of alginate-based microcapsules $[3,5,15,19-24]$. The impurities in alginate may explain the inconsistency regarding the bio-incompatibility of alginate microcapsules reported in the literature. In short, both the composition and purity determine the biocompatibility of alginate.

To increase their stability and to reduce the wall permeability (for immunoisolation) of the microcapsules, the plain alginate microcapsules are often coated first with a polycation and then another layer of alginate. Various polycations have been used including poly- $L$-lysine (PLL), poly- $L$-ornithine (PLO), chitosan, lactose modified chitosan and photopolymerized materials [11]. Among them, PLL is most commonly used to produce the classic alginate-PLL-alginate (APA) microcapsules. PLL binds to the alginate molecules next to the capsule surface by forming complexes with the M-G sequences in alginate, which decreases the porosity of the microcapsule wall. When the two molecules interact strongly, the PLL is converted from $\beta$-sheet to $\alpha$-helix and surrounded by a larger helix of the alginate molecule $[3,6,15,20,25,26]$.

Chitosan, one kind of biodegradable polysaccharide with structural characteristics similar to glycosaminoglycans, has attracted much attention as an alternative polycation in preparing microcapsules. Chitosan has excellent cell affinity [27, 28], and can be obtained by the $N$-deacetylation of chitin, poly[ $\beta(1 \rightarrow 4)$-2-acetamido-2-deocy- $D$ glucopyranose]. Chitosan has been used to microencapsulate PC12 cells, R208F cells, Human RBCs, HepG2 cells, BHK-21 cells, chondrocytes, and bone marrow stem cells [19, 29 - 35]. However, the encapsulation process involving high molar mass chitosan $(>100 \mathrm{kDa}$ ) must be carried out under $\mathrm{pH}<6.0$ to ensure chitosan solubility, which is too acidic to most mammalian cells. Moreover, the coating using high molar mass chitosan takes a relatively long time (up to $30 \mathrm{~min}$ ). This prolonged exposure of mammalian cells to the low $\mathrm{pH}$ results in low cell viability after coating. In addition, the swelling and breaking of alginate-chitosan-alginate (ACA) microcapsules are difficult to overcome when liquefying the alginate core using sodium citrate solution $[19,36,37]$. Moreover, long-term biocompatibility of chitosan and other polycations in vivo needs to be further evaluated rigorously. Again, the origin, purity and properties of these materials should be taken into account in assessing their biocompatibility [38]. 
Table 1. A summary of commonly used materials for cell microencapsulation and their applications

\begin{tabular}{|c|c|c|c|c|c|}
\hline \multicolumn{3}{|c|}{ Materials } & Cell Type(s) & $\begin{array}{c}\text { Targeted Diseases or } \\
\text { Applications }\end{array}$ & References \\
\hline \multirow{11}{*}{$\frac{\bar{\pi}}{\frac{\pi}{2}}$} & \multirow{6}{*}{ Alginate } & Alginate-PLL* & $\begin{array}{l}\text { Islets, hepatocytes, HEK } \\
293 \text { cells, mesenchymal } \\
\text { stem cells, embryonic } \\
\text { stem cells }\end{array}$ & $\begin{array}{l}\text { Diabetes, cancer, liver } \\
\text { neurodegenerative, } \\
\text { musculoskeletal, and } \\
\text { cardiovascular } \\
\text { diseases, etc. }\end{array}$ & {$[1-10]$} \\
\hline & & $\begin{array}{l}\text { Alginate- } \\
\text { chitosan }\end{array}$ & $\begin{array}{l}\text { PC12 cells, R208F cells, } \\
\text { Human RBCs, HepG2 } \\
\text { cells, BHK-21 cells, } \\
\text { chondrocytes, and bone } \\
\text { marrow stem cells }\end{array}$ & $\begin{array}{l}\text { Liver failure treatment, } \\
\text { myocardial therapy, } \\
\text { bone tissue } \\
\text { engineering, etc. }\end{array}$ & {$[18,28-34]$} \\
\hline & & Alginate-PLO* & $\begin{array}{l}\text { Rat islets with Sertoli's } \\
\text { cells }\end{array}$ & Diabetes & {$[137]$} \\
\hline & & Alginate-PEG* & Islets & Diabetes & {$[138]$} \\
\hline & & Alginate-gelatin & $\begin{array}{l}\text { Feline renal fibroblast } \\
\text { cells }\end{array}$ & $\begin{array}{l}\text { Regenerative } \\
\text { medicine and drug } \\
\text { research }\end{array}$ & [102] \\
\hline & & $\begin{array}{c}\text { Alginate-gelatin- } \\
\text { poly(vinyl } \\
\text { alcohol)-acrylic } \\
\text { terpolymer }\end{array}$ & Hepatocytes & Liver diseases & [139] \\
\hline & \multirow{2}{*}{\multicolumn{2}{|c|}{ Agarose }} & $\begin{array}{c}\text { Ifosfamide-activating } \\
\text { cells }\end{array}$ & Cancer & {$[140]$} \\
\hline & & & $\begin{array}{l}\text { Marrow stromal and } \\
\text { embryonic stem cells }\end{array}$ & $\begin{array}{c}\text { Regenerative } \\
\text { medicine and tissue } \\
\text { engineering }\end{array}$ & {$[116,141]$} \\
\hline & & Dollagen & Mesenchymal stem cells & $\begin{array}{l}\text { Bone tissue } \\
\text { engineering }\end{array}$ & {$[86]$} \\
\hline & \multirow{2}{*}{\multicolumn{2}{|c|}{ Hyaluronic acid }} & Embryonic stem cells & $\begin{array}{l}\text { Regenerative } \\
\text { medicine }\end{array}$ & {$[142]$} \\
\hline & & & $\begin{array}{l}\text { Human dermal } \\
\text { fibroblasts }\end{array}$ & $\begin{array}{l}\text { Reduce scar formation } \\
\text { and fibrotic disorders }\end{array}$ & [143] \\
\hline \multirow{4}{*}{ ڤ } & Poly & vinyl alcohol) & Islets & Diabetes & {$[144,145]$} \\
\hline & \multirow{2}{*}{\multicolumn{2}{|c|}{ 2-hydroxyethyl methacrylate }} & $\begin{array}{c}3 \mathrm{~T} 3 \text { fibroblasts } \\
\mathrm{CHO}-\mathrm{K} 1\end{array}$ & CNS diseases & {$[146]$} \\
\hline & & & $\begin{array}{l}\text { Luciferase-modified } \\
\text { CHO fibroblasts }\end{array}$ & $\begin{array}{l}\text { Down regulate } \\
\text { xenogenic immune } \\
\text { response }\end{array}$ & {$[147]$} \\
\hline & \multicolumn{2}{|c|}{ Poly(lactic-co-glycolic acid) } & $\begin{array}{l}\text { P19 embryonic } \\
\text { carcinoma cells }\end{array}$ & $\begin{array}{l}\text { Nerve tissue } \\
\text { engineering }\end{array}$ & {$[145]$} \\
\hline
\end{tabular}

\subsection{Methods for Cell Microencapsulation}

A number of methods have been used to prepare cell-loaded microcapsules, including extrusion (electrostatic spray, air flow nozzle, and vibrating nozzle), emulsion/thermal gelation (agarose as core polymer), and microfluidic flow focusing approach [14, 39 46]. The two main factors that should be considered when choosing a microencapsulation method are the capability of maintaining high cell viability/function and controlling microcapsule size (including size distribution) and shape. 
In emulsion methods, the aqueous phase (with living cells) is mixed and dispersed in an organic phase. When the dispersion reaches equilibrium, gel formation is initiated by cooling or by the addition of a gelling agent. Although the emulsion process could be easily scaled up, it has disadvantages including cell death caused by the significant shearing stress during emulsion and wide (Gaussian) size distribution [40]. In microfluidic methods based on flow focusing, miniaturized devices are used for better control of microcapsule characteristics. However, this method requires the use of organic solvents that makes it difficult to retrieve the microencapsulated cells [40, 47]. In extrusion methods, a cell/polymer mixture is extruded through a small tube or needle. The drops formed are allowed to fall freely into a gelation bath where the polymers are cross-linked to form hydrogel. The differences between the various extrusion methods are the driving force for extrusion and the method for liquid break up. Among them, the electrostatic spray method is promising because of the ease of operation, high efficiency, negligible damage to cells, and the possibility of preparing the microcapsules in a sterile environment [19, 40, 48].

In addition, there are non-traditional cell encapsulation techniques available. For example, cells have been encapsulated in hollow fiber for different in vivo transplantation needs and to improve the cell encapsulation efficiency and homogeneity of cell distribution within the biomatrix. Several hollow fiber systems have been developed for cell encapsulation with promising results, including poly(acrylonitrilevinyl chloride) (PAN-PVC) hollow fiber membrane [49], gelatinhydroxyphenylpropionic acid hydrogel fiber [50], and alginate hollow fiber [51].

\subsection{Cells Studied for Microencapsulation}

A variety of cells have been studied for cell microencapsulation in the following three categories:

Primary cells — Primay cells are cells taken directly from a living organism, which is not immortalised, such as islets. Transplantation of encapsulated islets or islet cell aggregates, the first cell source used in microencapsulation for diabetes treatment, has been the most common application of cell encapsulation technology to date [3 - 5, 52 - 56]. Moreover, microencapsulation of human islets has been applied in clinical trials $[57,58]$. Besides diabetes, primary cells have also been microencapsulated for treating neurodegenerative disorders (by transplantation of encapsulated choroid plexus), liver diseases (by transplantation of encapsulated hepatocytes), and neuropathic pain (by transplantation of encapsulated chromaffin cells) [59 - 64]. In addition, these studies have shown that microcapsules can serve as a $3 \mathrm{D}$ system to promote the survival and growth of the primary cells [63, 64].

Genetically engineered cells — Genetically modified cells have been microencapsulated to serve as a living therapeutic delivery agent. This provides a promising way for the treatment of chronic diseases which require sustained release of therapeutic agents. However, considering most genetically engineered cells are from allogenetic or xenogeneic sources, immunoisolation is an important factor for the use of these cells. Research using these cells has been conducted for the treatment of diseases in the central nervous system, cardiovascular disorders, mucopolysaccharidosis type VII (MPSVII) disease, anemia, wound, bone fractures, and 
cancer [65 - 74]. A Phase I trial of ciliary neurotrophic factor (CNTF) delivered by intraocular implants of encapsulated cells has been completed by Sieving et al. [75] The results show that delivery of CNTF using encapsulated cells is safe for the human retina even with severely compromised photoreceptors. Since a wide range of therapeutic agents can be produced by genetically engineered cells, this approach for delivering therapeutic products provides a potential therapy not only for retinal neurodegeneration but many other diseases.

Stem cells - Microencapsulation of stem cells as a therapeutic strategy for regenerative medicine, tissue engineering and gene therapy (stem cell as gene carrier) is an area of increasing interest [3, $76-80]$. Moreover, microcapsule can be adopted as a 3D microenvironment to study the proliferation and desired differentiation of embryonic stem cells and bone marrow (BM)-derived mesenchymal stem cells (MSCs) cells $[81,82]$. Maintenance of their undifferentiated characteristics and induction of specific differentiation of stem cells has been investigated [83 - 91]. Work by Maguire et al. [84] on embryonic stem (ES) cell encapsulation using alginate-PLL polymers showed high cell viability even post-decapsulation in vitro (>90\%). Evaluation of the hepatocyte-specific functions such as albumin synthesis and urea secretion revealed that the encapsulated cells adopted hepatogenic differentiation. Cardiac cells could also be generated from encapsulated ES cells in alginate-PLL microcapsules [92]. Both mouse and human MSCs have been differentiated into osteogenic lineages in microcapsules [86, 93]. Moreover, MSCs can act as feeder cells. Co-encapsulation of MSC and hepatocytes was found to enhance the viability and function of hepatocytes in vitro and in vivo [61, 77, 94, 95]. Studies have also been conducted on osteogenic differentiation of ES cells in alginate hydrogel and formation of embryoid body-like spherical tissues in hollow-core agarose microcapsules [96, 97]. Microcapsules can be used to encapsulate human ES cells into definitive endoderm for myocardial cell therapy $[81,98,99]$. Encapsulated stem cells could also be used as a tool for stem-cell mediated cardiomyoplasty [76]. Moreover, previous research has shown that both the intrinsic characteristics of stem cells and their microenvironment regulate the fate of stem cells $[76,96,100,101]$. In particular, the cells may produce auto-regulatory proteins during differentiation/maturation. Microcapsules may either induce or conserve this resource by retaining them within the capsules (autocrine effects). Many paracrine responses may direct differentiation/maturation (e.g., spontaneous ES differentiation into hepatocytes via embryoid body culture) [76, 96, 100, 101]. Therefore, the main objective of stem cell microencapsulation technology is to maintain the undifferentiated state of the cells and for controlled differentiation with the desired functions of the differentiated cells.

\section{ENCAPSULATION OF MAMMALIAN CELLS IN SMALL $(\leq \sim 100 \mu \mathrm{m})$ MICROCAPSULES}

Several recent studies highlight the importance of reducing the microcapsule size for cell-based medicine [11, 19, 102]. Small microcapsules offer many advantages in transplantation, considering that clinical practice of microencapsulation technology has been limited by the sites of transplantation and inadequate transport of nutrients to encapsulated cells $[5,7,102]$. For a sphere, the specific surface area (the surface area 
per unit volume) increases as the diameter decreases. Therefore, decrease in microcapsule diameter should reduce resistance to the transport of oxygen and nutrients to the encapsulated cells and enhance transfer of therapeutic products produced by the cells out of the microcapsule [5, 7, 102 - 104]. Moreover, small microcapsules have been shown to have better mechanical properties and stability that lead to better biocompatibility (presumably by minimizing the chance of microcapsule burst) [43, $102,104,105]$. For example, agarose microcapsules $\leq \sim 100 \mu \mathrm{m}$ in diameter were shown to be more biocompatible than that of 300-1000 $\mu \mathrm{m}[102,106,107]$. Remarkably, it has been reported that reduction in capsule size mitigates foreign body response to implanted microcapsules in host [108], reduces surgical trauma and allows more choices of implantation sites, especially immune-privileged sites such as the spleen [7, 102, 103]. Moreover, it has been reported that cryopreservation of microencapsulated cells is challenging when the size of the microcapsules exceeds 200 $\mu \mathrm{m}$ (more details in section 4) [109]. Using small cell-loaded microcapsules could improve the cell viability post cryopreservation, particularly by ultrafast vitrification [110-112].

Successful preparation of small cell-loaded alginate microcapsules from 100 to 200 $\mu \mathrm{m}$ (in diameter) has been reported in several recent studies using microfluidic channel/nozzle devices [7, 43, 103, 105, 113-116]. However, cell-loaded microcapsules prepared using the electrostatic spray method reported in the literature are usually greater than $200 \mu \mathrm{m}$. Considering the advantages of electrostatic spray method as discussed in the previous section, we have successfully applied it to encapsulate mammalian cells in small $(\sim 100 \mu \mathrm{m})$ alginate microcapsules with good morphology and high cell viability ( $>95 \%)$ by optimizing the manufacturing parameters [117].

\section{CRYOPRESERVATION OF MICROENCAPSULATED CELLS}

Successful cryopreservation of microencapsulated cells can promote their availability as cell-based medicine, by establishing banks of living cells for wide distribution to end users whenever needed. Cryopreservation of microencapsulated cells has been investigated through both slow freezing (i.e., phase change of water from liquid to ice crystals) and vitrification (i.e., the transformation of liquid water into an amorphous, solid like material instead of ice crystals) over the past 15 years [118 - 120]. Efforts have been made to optimize the cryopreservation protocol for maintaining cell viability and function as well as the integrity of the microcapsules [118 - 120]. However, the fundamental biophysics of the microencapsulated cells in response to temperature and osmotic excursion (due to cryoprotective agents (CPA) addition and freezing induced dehydration) during cryopreservation has not been well studied.

\subsection{Cryopreservation of Microencapsulated Cells by Slow-Freezing}

The slow-freezing method has been employed to cryopreserve a number of microencapsulated cells as detailed below.

Hepatocytes — Canaple et al. [121] encapsulated Murine hepatocytes in specially designed multicomponent capsules formed by polyelectrolyte complexation of sodium alginate, cellulose sulphate and poly(methylene-co-guanidine) hydrochloride. Encapsulated hepatocytes retained their specific functions for a long period after 
cryopreservation by slow freezing involving the following procedures: microencapsulated hepatocytes with CPA (10\% dimethyl sulfoxide (DMSO)) in cryovials were stored at $4^{\circ} \mathrm{C}$ for $30 \mathrm{~min},-20^{\circ} \mathrm{C}$ for $2 \mathrm{~h},-80^{\circ} \mathrm{C}$ for $24 \mathrm{~h}$, and then stored in liquid nitrogen $\left(-196^{\circ} \mathrm{C}\right)$. However, the freezing process was not well controlled (ice formation in aqueous solution is a stochastic event when cooled at $-20^{\circ} \mathrm{C}$ ) which may lead to inconsistent results. Moreover, the cell viability was not high (15\% of cell viability loss) and broken microcapsules were observed after cryopreservation [121]. Haque et al. [32] investigated the ability of Alginate-Chitosan (AC) microcapsules to support hepatocyte proliferation and function, and showed improved performance compared with the widely studied APA membrane in terms of both immunogenicity and cryopreservation properties. However, the structural differences of APA (hollow core) and AC (solid core) microcapsules were not considered.

Islets — Different kinds of islets have been successfully cryopreserved after microencapsulation. Two slow-cooling protocols were compared in Zhou's study [122]: (1) seeding extracellular ice at $-7.5^{\circ} \mathrm{C}$, cooling to $-45^{\circ} \mathrm{C}$ at $0.2^{\circ} \mathrm{C} / \mathrm{min}$, and then plunging in liquid nitrogen, and (2) cooling from 4 to $-70^{\circ} \mathrm{C}$ at $1{ }^{\circ} \mathrm{C} / \mathrm{min}$ directly without ice seeding (note: ice seeding means seeding extracellular ice at a high sub-zero temperature usually $>-10^{\circ} \mathrm{C}$ ). The two procedures yielded significantly different results when applied to porcine islets. It was noted that a closely controlled cooling rate is necessary in dealing with the delicate and sensitive porcine islets. In addition, ice seeding played a significant role in retaining the physiological competence of the cryopreserved islets. These factors make the cryopreservation protocol complicated and time-dependent, restricting its further applications. Two slow-freezing protocols (with ice-seeding), with a difference only in cooling rate $\left(0.3\right.$ versus $\left.5^{\circ} \mathrm{C} / \mathrm{min}\right)$, were compared in Li's study [48]. Only slight differences were observed. The possible reason is that the two cooling rates were both slow enough to dehydrate the cells, and/or the ice seeding step was more important than cooling rate in determining the cell viability and function post cryopreservation by slow freezing. Stiegler et al. [123] investigated cryopreservation of insulin-producing cells (HIT-T15) in sodium cellulose sulfate. The results showed that the cryoprotective capability of glycerol was similar to DMSO for non-encapsulated cells but better than DMSO for microencapsulated cells. The effect of microencapsulation on the morphology and endocrine function of cryopreserved neonatal porcine islet-like cell clusters (ICCs) was also studied [124]. The results suggested that microencapsulation is useful for cryopreserved ICCs to effectively maintain their fine morphology and to recover their endocrine function. Woods et al. [125] investigated the effect of two cryoprotectants (DMSO and ethylene glycol) on the volume change of $\mathrm{Ca}^{2+}$ alginate microcapsules, and the effects of microencapsulation on the volumetric response of human and canine pancreatic islets during cryoprotectant equilibration. The results demonstrate that there are cryoprotectant and alginate-specific interactions, and that microencapsulation modulates the degree of osmotically induced shrinkage of islets. The development or modification of existing cryopreservation protocols to improve post-cryopreservation recovery or function should take these factors into account.

Other Cells — Cryopreservation of microencapsulated kidney, PC 12 and transgenic cells has also been investigated $[118,119,126]$. For example, Heng et al. 
[118] used a slow-freezing protocol (cooling at $3 \sim 4^{\circ} \mathrm{C} / \mathrm{min}$ from room temperature to $80^{\circ} \mathrm{C}$ ) for the cryopreservation of microencapsulated kidney cells. A high concentration of cryoprotectant (2.8 M DMSO and $0.25 \mathrm{M}$ sucrose) was reported to be required for maintaining high cell viability post cryopreservation. Nevertheless, microcapsule integrity was still compromised $(\sim 60 \%$ intact $)$ at this high cryoprotectant concentration. Murua et al. [127] investigated the long-term storage of microencapsulated myoblasts by cryopreservation. A total of $10 \%$ DMSO was used as the cryoprotectant for a slow-freezing procedure $\left(1 \mathrm{~h}\right.$ cooling at $-20^{\circ} \mathrm{C}$, and $23 \mathrm{~h}$ cooling at $-80^{\circ} \mathrm{C}$, followed by cooling in liquid nitrogen). However, a $42 \%$ reduction in Epo release from the encapsulated cells after cryopreservation was noted, which may be a result of the use of a sub-optimal cryopreservation protocol (i.e., without ice-seeding) and the relative large microcapsule $(>400 \mu \mathrm{m})$ for encapsulating the cells. More recently, cryopreservation of microencapsulated neurospheres was also studied with promising outcome [128]. Moreover, application of cryopreserved transgenic mesenchymal stem-cell-loaded capsules $(500-600 \mu \mathrm{m})$ in intracerebral hemorrhage treatment has entered the stage of clinical trial [129].

\subsection{Cryopreservation of Microencapsulated Cells by Vitrification}

Although slow-freezing can provide utilitarian (but sub-optimal) outcome for banking microencapsulated cells, cell injury due to ice formation either inside or outside the cells is inevitable. Significant intracellular ice formation is lethal to the cells and extracellular ice formation may induce significant cell dehydration that can cause physicochemical injury to the encapsulated cells. Moreover, the loss of integrity of the relatively large $(\sim 250 \mu \mathrm{m})$ microcapsule was observed during slow-freezing, which may mechanically damage the encapsulated cells [118]. An alternative approach for cryopreservation is vitrification, transformation of liquid water into a solid-like, glassy substance with negligible ice formation (i.e., glass transition or cooling without freezing) $[130,131]$. A few studies have reported cryopreservation of microencapsulated cells through vitrification with an unusually high (up to $7 \mathrm{M}$ ) concentration of cryoprotectants [132, 133]. Although the results show that vitrification is superior to slow-freezing in maintaining both the cell viability/function and the microcapsule integrity, the potential osmotic and metabolic damage to the encapsulated cells by the usually high concentration of cryoprotectants is still a significant concern. Recently, we reported morphological and biophysical observations, using cryomicroscopy and scanning calorimetry, of small $(\sim 100 \mu \mathrm{m})$ alginate microcapsules after cryopreservation [134]. It was found that water enclosed in the microcapsules could be preferentially vitrified at a low concentration of cryoprotectants (10\% DMSO) when cooled at $100^{\circ} \mathrm{C} / \mathrm{min}$. As a result, microencapsulation of living cells in a small alginate microcapsules significantly augments cell survival $(\sim 90 \%$ for encapsulated cells versus $\sim 42 \%$ for non encapsulated cells, Figure 2 ) after cryopreservation with $10 \%$ DMSO and cooling the cells contained in $400 \mu \mathrm{m}$ quartz microcapillaries in liquid nitrogen. Therefore, the small alginate microcapsule is good for not only encapsulating stress-sensitive (to ice formation and high concentration of cryoprotectants) living cells but protecting the cells from cryoinjury during cryopreservation [134]. 

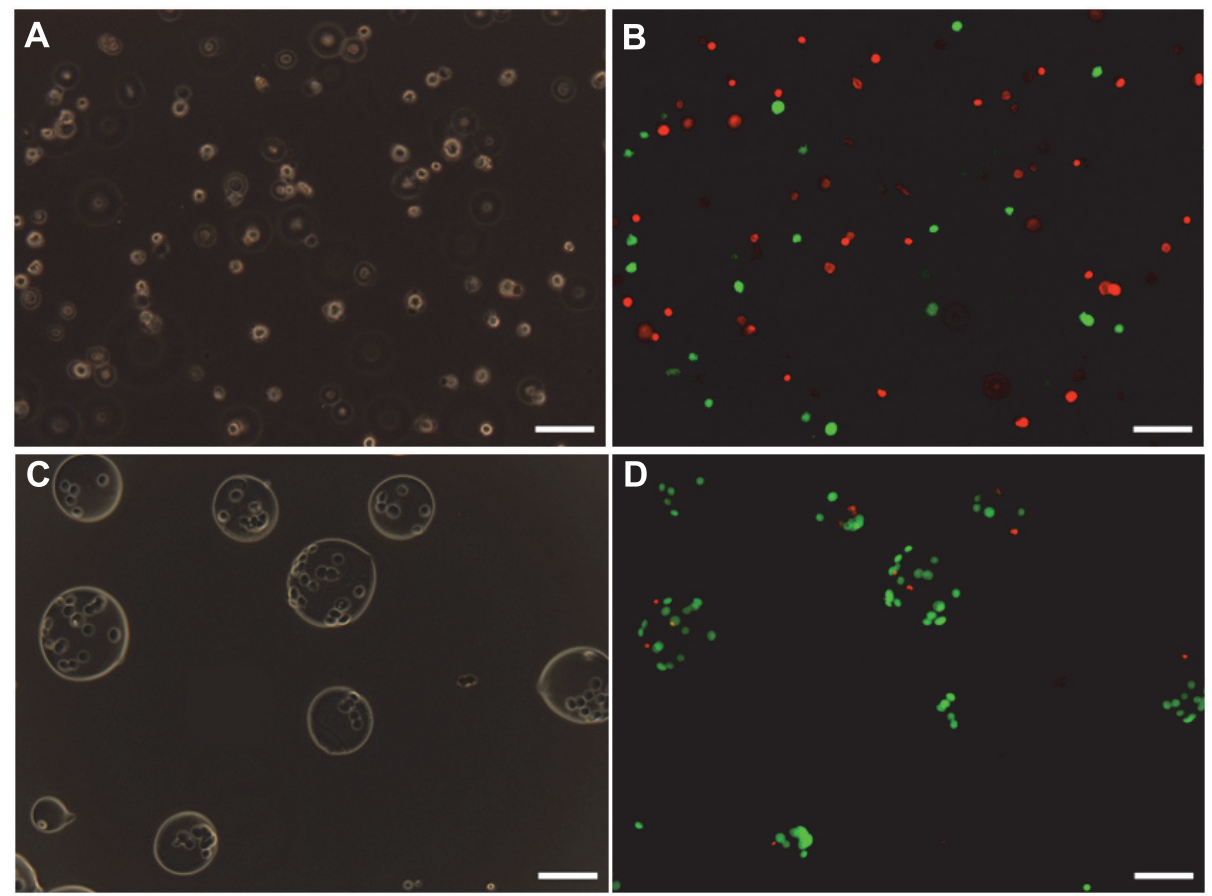

Figure 2. Phase contrast (A and C) and fluorescence micrographs (B and D) of nonencapsulated (A and B) and encapsulated (C and D) cells after cryopreservation by vitrification. In the fluorescence micrographs (B and D), live and dead cells were stained green and red, respectively. The cell viability were high (> 95\%) for both encapsulated and non-encapsulated cells before cryopreservation. Scale bars: $100 \mu \mathrm{m}$. Figure reprinted and redrawn from reference [134] with permission from Springer Publishing Co.

\section{CHALLENGES OF CELL MiCROENCAPSULATION FOR CLINICAL APPLICATIONS}

Although the technology of cell microencapsulation has been greatly improved with promising outcomes even in clinical trials and clinical practices [57, 58, 71, 75], there are still several limitations that need to be overcome. Firstly, the systemic biocompatibility of encapsulated cells needs to be enhanced. The fibrotic overgrowth (see Figure 3) may occur due to serious host immune response that can result in cell death (transplantation failure) through complicated mechanisms including the production of excessive free radicals. Moreover, necrosis may occur due to the use of improper encapsulation materials and/or an insufficient supply of nutrition. Dying cells may compromise the healthy neighboring cells and elicit antigenic responses in the long run [135]. Therefore, a high in vivo survival rate of encapsulated cells has to be achieved to ensure successful transplantation. This requires that the biomaterials used 
are systemically biocompatible and the microcapsule is capable of functioning as a semi-permeable membrane with proper porosity to protect the encapsulated cells from host immune attack while ensuring adequate supply of nutrients and discharge of metabolic wastes. Secondly, capsule breakage (see Figure 3) after transplantation may occur if the mechanical strength and stability of the microcapsules is poor. Cell leakage may lead to serious immune responses and other unexpected consequences. Thirdly, it may be difficult to develop one type of microcapsule system for all kinds of cells. For example, microcapsules made of non-biodegradable materials may not be suitable for applications that need tissue integration of the encapsulated cells. Lastly, regulatory considerations of the encapsulated cells in clinical practice need to be taken into account [136]. Therefore, a standard for comprehensive characterization of surface properties, permeability, mechanical strength, and other properties has to be established to ensure systemic biocompatibility and stability of the microcapsules [38].

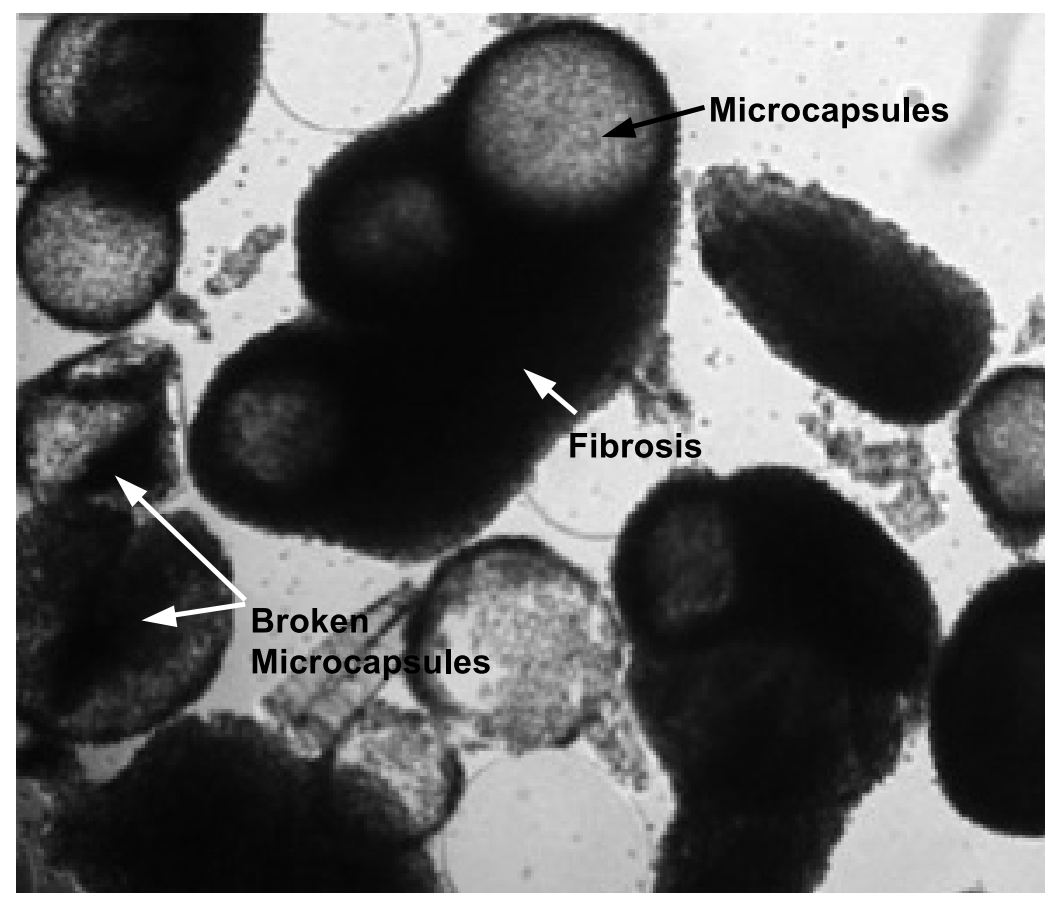

Figure 3. Fibrosis around encapsulated cells and broken microcapsules 2 days after transplantation, due to poor systemic biocompatibility and low mechanical stability/strength of microcapsules to encapsulate living cells. Figure reprinted and redrawn from reference [138] with permission from Elsevier. 


\section{SUMMARY AND OUTLOOK}

Cell microencapsulation is a promising technology to advance the emerging living-cellbased medicine. However, it is important to further improve the in vivo biocompatibility of the microcapsule systems by identifying systemically biocompatible materials to synthesize microcapsules and by reducing the size of the microcapsules. Further, the microcapsules should be designed with desired mechanical strength for stability and the desired porosity for adequate biotransport of nutrients and metabolic wastes. In addition, microcapsules with an appropriate extracellular matrix (e.g., collagen) in their core and co-encapsulation of multiple types of cells (e.g., both stromal and parenchymal) for better cell attachment and survival/function could be another important future direction. Banking the microencapsulated cells has been achieved mainly by cryopreservation via slow-freezing. On the other hand, vitrification of the microencapsulated cells is becoming increasingly popular as it can retain not only a high cell viability/function but also intact microcapsule morphology, particularly when vitrification is achieved with a low, nontoxic concentration $(\leq \sim 1.5 \mathrm{M})$ of cryoprotectants. For clinical implementation of cell-based medicine, it is desirable to bank the living cell-based products at the ambient temperature, an area that deserves further research. The biophysical responses of encapsulated cells to cooling/freezing and drying should be investigated for the development of optimal cryo and dry (lyo) preservation protocols.

\section{ACKNOWLEDGEMENTS}

This work was partially supported by grants from the National Science Foundation (CBET-1154965) and National Institute of Biomedical Imaging and Bioengineering of the National Institutes of Health (R01EB012108). We thank Kyle Gilstrap for proofreading this manuscript.

\section{CONFLICT OF INTEREST: None.}

\section{REFERENCES}

[1] Chang TM. Semipermeable Microcapsules. Science, 1964, 146:524-525.

[2] Lim F, Sun AM. Microencapsulated Islets as Bioartificial Endocrine Pancreas. Science, 1980, 210(4472): 908-910.

[3] Murua A, Portero A, Orive G, Hernandez RM, de Castro M, Pedraz JL. Cell microencapsulation technology: towards clinical application. J Control Release, 2008, 132(2):76-83.

[4] Orive G, Hernandez RM, Gascon AR, Calafiore R, Chang TM, De Vos P, Hortelano G, Hunkeler D, Lacik I, Shapiro AM, Pedraz JL. Cell encapsulation: promise and progress. Nat Med, 2003, 9(1):104107.

[5] Orive G, Hernandez RM, Rodriguez Gascon A, Calafiore R, Chang TM, de Vos P, Hortelano G, Hunkeler D, Lacik I, Pedraz JL. History, challenges and perspectives of cell microencapsulation. Trends Biotechnol, 2004, 22(2):87-92.

[6] Uludag H, De Vos P, Tresco PA. Technology of mammalian cell encapsulation. Adv Drug Deliv Rev, 2000, 42(1-2):29-64.

[7] Wilson JT, Chaikof EL. Challenges and emerging technologies in the immunoisolation of cells and tissues. Adv Drug Deliv Rev, 2008, 60(2):124-145. 
[8] Nafea EH, Poole-Warren AM, Martens PJ. Immunoisolating semi-permeable membranes for cell encapsulation: Focus on hydrogels. J Control Release, 2011, 154(2):110-122..

[9] Hernandez RM, Orive G, Murua A, Pedraz JL. Microcapsules and microcarriers for in situ cell delivery. Adv Drug Deliv Rev, 2010, 62(7-8):711-730.

[10] Batrakova EV, Gendelman HE, Kabanov AV. Cell-mediated drug delivery. Expert Opin Drug Deliv, 2011, 8(4):415-433.

[11] Santos E, Zarate J, Orive G, Hernandez RM, Pedraz JL. Biomaterials in cell microencapsulation. Adv Exp Med Biol, 2010, 670:5-21.

[12] Teramura Y, Iwata H. Bioartificial pancreas microencapsulation and conformal coating of islet of Langerhans. Adv Drug Deliv Rev, 2010, 62(7-8):827-840.

[13] Teramura Y, Minh LN, Kawamoto T, Iwata H. Microencapsulation of islets with living cells using polyDNA-PEG-lipid conjugate. Bioconjug Chem, 2010, 21(4):792-796.

[14] Smidsrød O, Skjåk-Braek G. Alginate as immobilization matrix for cells. Trends in Biotechnology, 1990, 8(3):71-78.

[15] de Vos P, Faas MM, Strand B, Calafiore R. Alginate-based microcapsules for immunoisolation of pancreatic islets. Biomaterials, 2006, 27(32):5603-5617.

[16] Morch YA, Donati I, Strand BL, Skjak-Braek G. Effect of $\mathrm{Ca} 2+, \mathrm{Ba} 2+$, and $\mathrm{Sr} 2+$ on alginate microbeads. Biomacromolecules, 2006, 7(5):1471-1480.

[17] Zimmermann H, Zimmermann D, Reuss R, Feilen PJ, Manz B, Katsen A, Weber M, Ihmig FR, Ehrhart F, Gessner P, Behringer M, Steinbach A, Wegner LH, Sukhorukov VL, Vasquez JA, Schneider S, Weber MM, Volke F, Wolf R, Zimmermann U. Towards a medically approved technology for alginatebased microcapsules allowing long-term immunoisolated transplantation. J Mater Sci Mater Med, 2005, 16(6):491-501.

[18] Qi M, Strand BL, Morch Y, Lacik I, Wang Y, Salehi P, Barbaro B, Gangemi A, Kuechle J, Romagnoli T, Hansen MA, Rodriguez LA, Benedetti E, Hunkeler D, Skjak-Braek G, Oberholzer J. Encapsulation of human islets in novel inhomogeneous alginate-ca2+/ba2+ microbeads: in vitro and in vivo function. Artif Cells Blood Substit Immobil Biotechnol, 2008, 36(5):403-420.

[19] Zhang WJ, Li BG, Zhang C, Xie XH, Tang TT. Biocompatibility and membrane strength of C3H10T1/2 cell-loaded alginate-based microcapsules. Cytotherapy, 2008, 10(1):90-97.

[20] Orive G, Tam SK, Pedraz JL, Halle JP. Biocompatibility of alginate-poly-L-lysine microcapsules for cell therapy. Biomaterials, 2006, 27(20):3691-3700.

[21] van Schilfgaarde R, de Vos P. Factors influencing the properties and performance of microcapsules for immunoprotection of pancreatic islets. J Mol Med, 1999, 77(1):199-205.

[22] Clayton HA, London NJ, Colloby PS, Bell PR, James RF. The effect of capsule composition on the biocompatibility of alginate-poly-1-lysine capsules. J Microencapsul, 1991, 8(2):221-233.

[23] Mallett AG, Korbutt GS. Alginate modification improves long-term survival and function of transplanted encapsulated islets. Tissue Eng Part A, 2009, 15(6):1301-1309.

[24] Menard M, Dusseault J, Langlois G, Baille WE, Tam SK, Yahia L, Zhu XX, Halle JP. Role of protein contaminants in the immunogenicity of alginates. J Biomed Mater Res B Appl Biomater, 2010, 93(2):333-340.

[25] Thu B, Bruheim P, Espevik T, Smidsrod O, Soon-Shiong P, Skjak-Braek G. Alginate polycation microcapsules. I. Interaction between alginate and polycation. Biomaterials, 1996, 17(10):1031-1040.

[26] Thu B, Bruheim P, Espevik T, Smidsrod O, Soon-Shiong P, Skjak-Braek G. Alginate polycation microcapsules. II. Some functional properties. Biomaterials, 1996, 17(11):1069-1079.

[27] De S, Robinson D. Polymer relationships during preparation of chitosan-alginate and poly-1-lysinealginate nanospheres. J Control Release, 2003, 89(1):101-112.

[28] Chung HJ, Go DH, Bae JW, Jung IK, Lee JW, Park KD. Synthesis and characterization of Pluronic((R)) grafted chitosan copolymer as a novel injectable biomaterial. Current Applied Physics, 2005, 5(5):485-488. 
[29] Baruch L, Machluf M. Alginate-chitosan complex coacervation for cell encapsulation: effect on mechanical properties and on long-term viability. Biopolymers, 2006, 82(6):570-579.

[30] Chandy T, Mooradian DL, Rao GH. Evaluation of modified alginate-chitosan-polyethylene glycol microcapsules for cell encapsulation. Artif Organs, 1999, 23(10):894-903.

[31] Haque T, Chen H, Ouyang W, Martoni C, Lawuyi B, Urbanska A, Prakash S. Investigation of a new microcapsule membrane combining alginate, chitosan, polyethylene glycol and poly-L-lysine for cell transplantation applications. Int J Artif Organs, 2005, 28(6):631-637.

[32] Haque T, Chen H, Ouyang W, Martoni C, Lawuyi B, Urbanska AM, Prakash S. In vitro study of alginate-chitosan microcapsules: an alternative to liver cell transplants for the treatment of liver failure. Biotechnol Lett, 2005, 27(5):317-322.

[33] Marsich E, Borgogna M, Donati I, Mozetic P, Strand BL, Salvador SG, Vittur F, Paoletti S. Alginate/lactose-modified chitosan hydrogels: A bioactive biomaterial for chondrocyte encapsulation. Journal of Biomedical Materials Research Part A, 2008, 84A(2):364-376.

[34] Paul A, Shum-Tim D, Prakash S. Investigation on PEG Integrated Alginate-Chitosan Microcapsules for Myocardial Therapy Using Marrow Stem Cells Genetically Modified by Recombinant Baculovirus Cardiovascular Engineering and Technology, 2010, 1(2):154-164.

[35] Zielinski BA, Aebischer P. Chitosan as a matrix for mammalian cell encapsulation. Biomaterials, 1994, 15(13):1049-1056.

[36] Orive G, Bartkowiak A, Lisiecki S, De Castro M, Hernandez RM, Gascon AR, Pedraz JL. Biocompatible oligochitosans as cationic modifiers of alginate/Ca microcapsules. Journal of Biomedical Materials Research Part B-Applied Biomaterials, 2005, 74B(1):429-439.

[37] De Castro M, Orive G, Hernandez RM, Bartkowiak A, Brylak W, Pedraz JL. Biocompatibility and in vivo evaluation of oligochitosans as cationic modifiers of alginate/Ca microcapsules. J Biomed Mater Res A, 2009, 91(4):1119-1130.

[38] de Vos P, Bucko M, Gemeiner P, Navratil M, Svitel J, Faas M, Strand BL, Skjak-Braek G, Morch YA, Vikartovska A, Lacik I, Kollarikova G, Orive G, Poncelet D, Pedraz JL, Ansorge-Schumacher MB. Multiscale requirements for bioencapsulation in medicine and biotechnology. Biomaterials, 2009, 30(13):2559-2570.

[39] Acker JP. Biopreservation of cells and engineered tissues. Adv Biochem Eng Biotechnol, 2007, 103:157-187.

[40] Rabanel JM, Banquy X, Zouaoui H, Mokhtar M, Hildgen P. Progress technology in microencapsulation methods for cell therapy. Biotechnol Prog, 2009, 25(4):946-963.

[41] Koch S, Schwinger C, Kressler J, Heinzen C, Rainov NG. Alginate encapsulation of genetically engineered mammalian cells: comparison of production devices, methods and microcapsule characteristics. J Microencapsul, 2003, 20(3):303-316.

[42] Iwata H, Takagi T, Amemiya H, Shimizu H, Yamashita K, Kobayashi K, Akutsu T. Agarose for a bioartificial pancreas. J Biomed Mater Res, 1992, 26(7):967-977.

[43] Sugiura S, Oda T, Aoyagi Y, Matsuo R, Enomoto T, Matsumoto K, Nakamura T, Satake M, Ochiai A, Ohkohchi N, Nakajima M. Microfabricated airflow nozzle for microencapsulation of living cells into 150 micrometer microcapsules. Biomed Microdevices, 2007, 9(1):91-99.

[44] Haeberle S, Naegele L, Burger R, von Stetten F, Zengerle R, Ducree J. Alginate bead fabrication and encapsulation of living cells under centrifugally induced artificial gravity conditions. J Microencapsul, 2008, 25(4):267-274.

[45] Batorsky A, Liao J, Lund AW, Plopper GE, Stegemann JP. Encapsulation of adult human mesenchymal stem cells within collagen-agarose microenvironments. Biotechnol Bioeng, 2005, 92(4):492-500.

[46] Wang L, Stegemann JP. Thermogelling chitosan and collagen composite hydrogels initiated with betaglycerophosphate for bone tissue engineering. Biomaterials, 2010, 31(14):3976-3985.

[47] Kim C, Lee KS, Kim YE, Lee KJ, Lee SH, Kim TS, Kang JY. Rapid exchange of oil-phase in microencapsulation chip to enhance cell viability. Lab Chip, 2009, 9(9):1294-1297. 
[48] Li BG, Hua TC, Zhang HD, Wang YF, Wang GX. Cryopreservation and xenotransplantation studies of microencapsulated rat pancreatic islets. Cryo Letters, 2002, 23(1):47-54.

[49] Kim YT, Hitchcock R, Broadhead KW, Messina DJ, Tresco PA. A cell encapsulation device for studying soluble factor release from cells transplanted in the rat brain. $J$ Control Release, 2005, 102(1):101-111.

[50] Hu M, Kurisawa M, Deng R, Teo CM, Schumacher A, Thong YX, Wang L, Schumacher KM, Ying JY. Cell immobilization in gelatin-hydroxyphenylpropionic acid hydrogel fibers. Biomaterials, 2009, 30(21):3523-3531.

[51] Hoesli CA, Luu M, Piret JM. A novel alginate hollow fiber bioreactor process for cellular therapy applications. Biotechnol Prog, 2009, 25(6):1740-1751.

[52] Ding HF, Liu R, Li BG, Lou JR, Dai KR, Tang TT. Biologic effect and immunoisolating behavior of BMP-2 gene-transfected bone marrow-derived mesenchymal stem cells in APA microcapsules. Biochem Biophys Res Commun, 2007, 362(4):923-927.

[53] Bohman S, King AJ. Islet alpha cell number is maintained in microencapsulated islet transplantation. Biochem Biophys Res Commun, 2008, 377(2):729-733.

[54] Teramura Y, Iwata H. Islet encapsulation with living cells for improvement of biocompatibility. Biomaterials, 2009, 30(12):2270-2275.

[55] O'Sullivan ES, Johnson AS, Omer A, Hollister-Lock J, Bonner-Weir S, Colton CK, Weir GC. Rat islet cell aggregates are superior to islets for transplantation in microcapsules. Diabetologia, 2010, 53(5):937-945.

[56] Schneider S, von Mach MA, Kraus O, Kann P, Feilen PJ. Intraportal transplantation of allogenic pancreatic islets encapsulated in barium alginate beads in diabetic rats. Artif Organs, 2003, 27(11):1053-1056.

[57] Calafiore R, Basta G, Luca G, Lemmi A, Racanicchi L, Mancuso F, Montanucci MP, Brunetti P. Standard technical procedures for microencapsulation of human islets for graft into nonimmunosuppressed patients with type 1 diabetes mellitus. Transplant Proc, 2006, 38(4):11561157.

[58] Calafiore R, Basta G, Luca G, Lemmi A, Montanucci MP, Calabrese G, Racanicchi L, Mancuso F, Brunetti P. Microencapsulated pancreatic islet allografts into nonimmunosuppressed patients with type 1 diabetes: first two cases. Diabetes Care, 2006, 29(1):137-138.

[59] Emerich DF, Thanos CG, Goddard M, Skinner SJ, Geany MS, Bell WJ, Bintz B, Schneider P, Chu Y, Babu RS, Borlongan CV, Boekelheide K, Hall S, Bryant B, Kordower JH. Extensive neuroprotection by choroid plexus transplants in excitotoxin lesioned monkeys. Neurobiol Dis, 2006, 23(2):471-480.

[60] Jeon Y, Kwak K, Kim S, Kim Y, Lim J, Baek W. Intrathecal implants of microencapsulated xenogenic chromaffin cells provide a long-term source of analgesic substances. Transplant Proc, 2006, 38(9):3061-3065.

[61] Shi XL, Zhang Y, Gu JY, Ding YT. Coencapsulation of hepatocytes with bone marrow mesenchymal stem cells improves hepatocyte-specific functions. Transplantation, 2009, 88(10):1178-1185.

[62] Teng Y, Wang Y, Li S, Wang W, Gu R, Guo X, Nan X, Ma X, Pei X. Treatment of acute hepatic failure in mice by transplantation of mixed microencapsulation of rat hepatocytes and transgenic human fetal liver stromal cells. Tissue Eng Part C Methods, 2010, 16(5):1125-1134.

[63] Miranda JP, Rodrigues A, Tostoes RM, Leite S, Zimmerman H, Carrondo MJ, Alves PM. Extending hepatocyte functionality for drug-testing applications using high-viscosity alginate-encapsulated three-dimensional cultures in bioreactors. Tissue Eng Part C Methods, 2010, 16(6):1223-1232.

[64] Tostoes RM, Leite SB, Miranda JP, Sousa M, Wang DI, Carrondo MJ, Alves PM. Perfusion of 3D encapsulated hepatocytes - a synergistic effect enhancing long-term functionality in bioreactors. Biotechnol Bioeng, 2011, 108(1):41-49.

[65] Dvir-Ginzberg M, Konson A, Cohen S, Agbaria R. Entrapment of retroviral vector producer cells in three-dimensional alginate scaffolds for potential use in cancer gene therapy. $J$ Biomed Mater Res B Appl Biomater, 2007, 80(1):59-66. 
[66] Han YF, Han YQ, Pan YG, Chen YL, Chai JK. Transplantation of microencapsulated cells expressing VEGF improves angiogenesis in implanted xenogeneic acellular dermis on wound. Transplant Proc, 2010, 42(5):1935-1943.

[67] Murua A, Orive G, Hernandez RM, Pedraz JL. Epo delivery by genetically engineered C2C12 myoblasts immobilized in microcapsules. Adv Exp Med Biol, 2010, 670:54-67.

[68] Nakama H, Ohsugi K, Otsuki T, Date I, Kosuga M, Okuyama T, Sakuragawa N. Encapsulation cell therapy for mucopolysaccharidosis type VII using genetically engineered immortalized human amniotic epithelial cells. Tohoku J Exp Med, 2006, 209(1):23-32.

[69] Salmons B, Gunzburg WH. Therapeutic application of cell microencapsulation in cancer. Adv Exp Med Biol, 2010, 670:92-103.

[70] Thanos CG, Bintz B, Emerich DF. Microencapsulated choroid plexus epithelial cell transplants for repair of the brain. Adv Exp Med Biol, 2010, 670:80-91.

[71] Yasuhara T, Date I. Intracerebral transplantation of genetically engineered cells for Parkinson's disease: toward clinical application. Cell Transplant, 2007, 16(2):125-132.

[72] Zhang H, Zhu SJ, Wang W, Wei YJ, Hu SS. Transplantation of microencapsulated genetically modified xenogeneic cells augments angiogenesis and improves heart function. Gene Ther, 2008, 15(1):40-48.

[73] Olabisi RM, Lazard ZW, Franco CL, Hall MA, Kwon SK, Sevick-Muraca EM, Hipp JA, Davis AR, Olmsted-Davis EA, West JL. Hydrogel microsphere encapsulation of a cell-based gene therapy system increases cell survival of injected cells, transgene expression, and bone volume in a model of heterotopic ossification. Tissue Eng Part A, 2010, 16(12):3727-3736.

[74] Awrey DE, Tse M, Hortelano G, Chang PL. Permeability of alginate microcapsules to secretory recombinant gene products. Biotechnol Bioeng, 1996, 52(4):472-484.

[75] Sieving PA, Caruso RC, Tao W, Coleman HR, Thompson DJ, Fullmer KR, Bush RA. Ciliary neurotrophic factor (CNTF) for human retinal degeneration: phase I trial of CNTF delivered by encapsulated cell intraocular implants. Proc Natl Acad Sci U S A, 2006, 103(10):3896-3901.

[76] Paul A, Ge Y, Prakash S, Shum-Tim D. Microencapsulated stem cells for tissue repairing: implications in cell-based myocardial therapy. Regen Med, 2009, 4(5):733-745.

[77] Liu ZC, Chang TM. Artificial cell microencapsulated stem cells in regenerative medicine, tissue engineering and cell therapy. Adv Exp Med Biol, 2010, 670:68-79.

[78] Moyer HR, Kinney RC, Singh KA, Williams JK, Schwartz Z, Boyan BD. Alginate microencapsulation technology for the percutaneous delivery of adipose-derived stem cells. Ann Plast Surg, 2010, 65(5):497-503.

[79] Heile AM, Wallrapp C, Klinge PM, Samii A, Kassem M, Silverberg G, Brinker T. Cerebral transplantation of encapsulated mesenchymal stem cells improves cellular pathology after experimental traumatic brain injury. Neurosci Lett, 2009, 463(3):176-181.

[80] Klinge PM, Harmening K, Miller MC, Heile A, Wallrapp C, Geigle P, Brinker T. Encapsulated native and glucagon-like peptide-1 transfected human mesenchymal stem cells in a transgenic mouse model of Alzheimer's disease. Neurosci Lett, 2011, 497(1):6-10.

[81] Chayosumrit M, Tuch B, Sidhu K. Alginate microcapsule for propagation and directed differentiation of hESCs to definitive endoderm. Biomaterials, 2010, 31(3):505-514.

[82] Dean SK, Yulyana Y, Williams G, Sidhu KS, Tuch BE. Differentiation of encapsulated embryonic stem cells after transplantation. Transplantation, 2006, 82(9):1175-1184.

[83] Evangelista MB, Hsiong SX, Fernandes R, Sampaio P, Kong HJ, Barrias CC, Salema R, Barbosa MA, Mooney DJ, Granja PL. Upregulation of bone cell differentiation through immobilization within a synthetic extracellular matrix. Biomaterials, 2007, 28(25):3644-3655.

[84] Maguire T, Davidovich AE, Wallenstein EJ, Novik E, Sharma N, Pedersen H, Androulakis IP, Schloss R, Yarmush M. Control of hepatic differentiation via cellular aggregation in an alginate microenvironment. Biotechnol Bioeng, 2007, 98(3):631-644.

[85] Yim EK, Wan AC, Le Visage C, Liao IC, Leong KW. Proliferation and differentiation of human mesenchymal stem cell encapsulated in polyelectrolyte complexation fibrous scaffold. Biomaterials, 2006, 27(36):6111-6122. 
[86] Chan BP, Hui TY, Wong MY, Yip KH, Chan GC. Mesenchymal stem cell-encapsulated collagen microspheres for bone tissue engineering. Tissue Eng Part C Methods, 2010, 16(2):225-235.

[87] Mehlhorn AT, Schmal H, Kaiser S, Lepski G, Finkenzeller G, Stark GB, Sudkamp NP. Mesenchymal stem cells maintain TGF-beta-mediated chondrogenic phenotype in alginate bead culture. Tissue Eng, 2006, 12(6):1393-1403.

[88] Penolazzi L, Tavanti E, Vecchiatini R, Lambertini E, Vesce F, Gambari R, Mazzitelli S, Mancuso F, Luca G, Nastruzzi C, Piva R. Encapsulation of mesenchymal stem cells from Wharton's jelly in alginate microbeads. Tissue Eng Part C Methods, 2010, 16(1):141-155.

[89] Trouche E, Fullana SG, Mias C, Ceccaldi C, Tortosa F, Seguelas MH, Calise D, Parini A, Cussac D, Sallerin B. Evaluation of alginate microspheres for mesenchymal stem cells engraftment on solid organ. Cell Transplant, 2010, 19(12):1623-1633.

[90] Park JS, Yang HN, Woo DG, Kim H, Na K, Park KH. Multi-lineage differentiation of hMSCs encapsulated in thermo-reversible hydrogel using a co-culture system with differentiated cells. Biomaterials, 2010, 31(28):7275-7287.

[91] Siti-Ismail N, Bishop AE, Polak JM, Mantalaris A. The benefit of human embryonic stem cell encapsulation for prolonged feeder-free maintenance. Biomaterials, 2008, 29(29):3946-3952.

[92] Jing D, Parikh A, Tzanakakis ES. Cardiac Cell Generation from Encapsulated Embryonic Stem Cells in Static and Scalable Culture Systems. Cell Transplant, 2010, 19(11):1397-1412.

[93] Endres M, Wenda N, Woehlecke H, Neumann K, Ringe J, Erggelet C, Lerche D, Kaps C. Microencapsulation and chondrogenic differentiation of human mesenchymal progenitor cells from subchondral bone marrow in Ca-alginate for cell injection. Acta Biomater, 2010, 6(2):436-444.

[94] Chang Liu Z, Chang TM. Coencapsulation of hepatocytes and bone marrow cells: in vitro and in vivo studies. Biotechnol Annu Rev, 2006, 12:137-151.

[95] Liu ZC, Chang TM. Coencapsulation of hepatocytes and bone marrow stem cells: in vitro conversion of ammonia and in vivo lowering of bilirubin in hyperbilirubemia Gunn rats. Int J Artif Organs, 2003, 26(6):491-497.

[96] Hwang YS, Cho J, Tay F, Heng JY, Ho R, Kazarian SG, Williams DR, Boccaccini AR, Polak JM, Mantalaris A. The use of murine embryonic stem cells, alginate encapsulation, and rotary microgravity bioreactor in bone tissue engineering. Biomaterials, 2009, 30(4):499-507.

[97] Sakai S, Hashimoto I, Kawakami K. Production of cell-enclosing hollow-core agarose microcapsules via jetting in water-immiscible liquid paraffin and formation of embryoid body-like spherical tissues from mouse ES cells enclosed within these microcapsules. Biotechnol Bioeng, 2008, 99(1):235-243.

[98] Al Kindi AH, Asenjo JF, Ge Y, Chen GY, Bhathena J, Chiu RC, Prakash S, Shum-Tim D. Microencapsulation to reduce mechanical loss of microspheres: implications in myocardial cell therapy. Eur J Cardiothorac Surg, 2010, 39(2):241-247.

[99] Yu J, Du KT, Fang Q, Gu Y, Mihardja SS, Sievers RE, Wu JC, Lee RJ. The use of human mesenchymal stem cells encapsulated in RGD modified alginate microspheres in the repair of myocardial infarction in the rat. Biomaterials, 2010, 31(27):7012-7020.

[100] Maguire T, Novik E, Schloss R, Yarmush M. Alginate-PLL microencapsulation: effect on the differentiation of embryonic stem cells into hepatocytes. Biotechnol Bioeng, 2006, 93(3):581-591.

[101] Wang X, Wang W, Ma J, Guo X, Yu X, Ma X. Proliferation and differentiation of mouse embryonic stem cells in APA microcapsule: A model for studying the interaction between stem cells and their niche. Biotechnol Prog, 2006, 22(3):791-800.

[102] Sakai S, Kawakami K. Development of subsieve-size capsules and application to cell therapy. Adv Exp Med Biol, 2010, 670:22-30.

[103] Sakai S, Kawabata K, Ono T, Ijima H, Kawakami K. Preparation of mammalian cell-enclosing subsieve-sized capsules (<100 microm) in a coflowing stream. Biotechnol Bioeng, 2004, 86(2):168173.

[104] Strand BL, Gaserod O, Kulseng B, Espevik T, Skjak-Baek G. Alginate-polylysine-alginate microcapsules: effect of size reduction on capsule properties. J Microencapsul, 2002, 19(5):615-630. 
[105] Ross CJ, Chang PL. Development of small alginate microcapsules for recombinant gene product delivery to the rodent brain. J Biomater Sci Polym Ed, 2002, 13(8):953-962.

[106] Sakai S, Mu C, Kawabata K, Hashimoto I, Kawakami K. Biocompatibility of subsieve-size capsules versus conventional-size microcapsules. J Biomed Mater Res A, 2006, 78(2):394-398.

[107] Sakai S, Kawabata K, Tanaka S, Harimoto N, Hashimoto I, Mu C, Salmons B, Ijima H, Kawakami K. Subsieve-size agarose capsules enclosing ifosfamide-activating cells: a strategy toward chemotherapeutic targeting to tumors. Mol Cancer Ther, 2005, 4(11):1786-1790.

[108] Robitaille R, Pariseau JF, Leblond FA, Lamoureux M, Lepage Y, Halle JP. Studies on small ( $<350$ microm) alginate-poly-L-lysine microcapsules. III. Biocompatibility Of smaller versus standard microcapsules. J Biomed Mater Res, 1999, 44(1):116-120.

[109] Chin Heng B, Yu H, Chye Ng S. Strategies for the cryopreservation of microencapsulated cells. Biotechnol Bioeng, 2004, 85(2):202-213.

[110] He X, Park EY, Fowler A, Yarmush ML, Toner M. Vitrification by ultra-fast cooling at a low concentration of cryoprotectants in a quartz micro-capillary: a study using murine embryonic stem cells. Cryobiology, 2008, 56(3):223-232.

[111] Berejnov V, Husseini NS, Alsaied OA, Thorne RE. Effects of cryoprotectant concentration and cooling rate on vitrification of aqueous solutions. Journal of Applied Crystallography, 2006, 39:244-251.

[112] Edd JF, Di Carlo D, Humphry KJ, Koster S, Irimia D, Weitz DA, Toner M. Controlled encapsulation of single-cells into monodisperse picolitre drops. Lab Chip, 2008, 8(8):1262-1264.

[113] Sugiura S, Oda T, Izumida Y, Aoyagi Y, Satake M, Ochiai A, Ohkohchi N, Nakajima M. Size control of calcium alginate beads containing living cells using micro-nozzle array. Biomaterials, 2005, 26(16):3327-3331.

[114] Shintaku H, Kuwabara T, Kawano S, Suzuki T, Kanno I, Kotera H. Micro cell encapsulation and its hydrogel-beads production using microfluidic device. Microsystem Technologies-Micro-and Nanosystems-Information Storage and Processing Systems, 2007, 13(8-10):951-958.

[115] Huang KS, Liu MK, Wu CH, Yen YT, Lin YC. Calcium alginate microcapsule generation on a microfluidic system fabricated using the optical disk process. J Micromech Microeng, 2007, 17(8):1428-1434.

[116] Karoubi G, Ormiston ML, Stewart DJ, Courtman DW. Single-cell hydrogel encapsulation for enhanced survival of human marrow stromal cells. Biomaterials, 2009, 30(29):5445-5455.

[117] Zhang W, He X. Encapsulation of living cells in small ( approximately 100 microm) alginate microcapsules by electrostatic spraying: a parametric study. J Biomech Eng, 2009, 131(7):074515.

[118] Heng BC, Yu YJ, Ng SC. Slow-cooling protocols for microcapsule cryopreservation. J Microencapsul, 2004, 21(4):455-467.

[119] Stensvaag V, Furmanek T, Lonning K, Terzis AJ, Bjerkvig R, Visted T. Cryopreservation of alginateencapsulated recombinant cells for antiangiogenic therapy. Cell Transplant, 2004, 13(1):35-44.

[120] Wu Y, Yu H, Chang S, Magalhaes R, Kuleshova LL. Vitreous cryopreservation of cell-biomaterial constructs involving encapsulated hepatocytes. Tissue Eng, 2007, 13(3):649-658.

[121] Canaple L, Nurdin N, Angelova N, Saugy D, Hunkeler D, Desvergne B. Maintenance of primary murine hepatocyte functions in multicomponent polymer capsules-in vitro cryopreservation studies. J Hepatol, 2001, 34(1):11-18.

[122] Zhou D, Vacek I, Sun AM. Cryopreservation of microencapsulated porcine pancreatic islets: in vitro and in vivo studies. Transplantation, 1997, 64(8):1112-1116.

[123] Stiegler PB, Stadlbauer V, Schaffellner S, Halwachs G, Lackner C, Hauser O, Iberer F, Tscheliessnigg K. Cryopreservation of insulin-producing cells microencapsulated in sodium cellulose sulfate. Transplant Proc, 2006, 38(9):3026-3030.

[124] Murakami M, Satou H, Kimura T, Kobayashi T, Yamaguchi A, Nakagawara G, Iwata H. Effects of micro-encapsulation on morphology and endocrine function of cryopreserved neonatal porcine isletlike cell clusters. Transplantation, 2000, 70(8):1143-1148. 
[125] Woods EJ, Liu J, Zieger MA, Lakey JR, Critser JK. The effects of microencapsulation on pancreatic islet osmotically induced volumetric response. Cell Transplant, 1999, 8(6):699-708.

[126] Matsumoto Y, Morinaga Y, Ujihira M, Oka K, Tanishita K. Improvement in the viability of cryopreserved cells by microencapsulation. JSME international journal Series C, Mechanical systems, machine elements and manufacturing, 2001, 67(654):580-587.

[127] Murua A, Orive G, Hernandez RM, Pedraz JL. Cryopreservation based on freezing protocols for the long-term storage of microencapsulated myoblasts. Biomaterials, 2009, 30(20):3495-3501.

[128] Malpique R, Osorio LM, Ferreira DS, Ehrhart F, Brito C, Zimmermann H, Alves PM. Alginate Encapsulation as a Novel Strategy for the Cryopreservation of Neurospheres. Tissue Eng Part C Methods, 2010, 16(5):965-977.

[129] GLP-1 CellBeads ${ }^{\circledR}$ for the Treatment of Stroke Patients With Space-occupying Intracerebral Hemorrhage (www.clinicaltrials.gov, ID: NCT01298830).

[130] Fahy GM, MacFarlane DR, Angell CA, Meryman HT. Vitrification as an approach to cryopreservation. Cryobiology, 1984, 21(4):407-426.

[131] Rall WF, Fahy GM. Ice-free cryopreservation of mouse embryos at -196 degrees C by vitrification. Nature, 1985, 313(6003):573-575.

[132] Agudelo CA, Iwata $\mathrm{H}$. The development of alternative vitrification solutions for microencapsulated islets. Biomaterials, 2008, 29(9):1167-1176.

[133] Kuleshova LL, Wang XW, Wu YN, Zhou Y, Yu H. Vitrification of encapsulated hepatocytes with reduced cooling and warming rates. Cryo Letters, 2004, 25(4):241-254.

[134] Zhang W, Yang G, Zhang A, Xu LX, He X. Preferential vitrification of water in small alginate microcapsules significantly augments cell cryopreservation by vitrification. Biomed Microdevices, 2010, 12(1):89-96.

[135] Lim GJ, Zare S, Van Dyke M, Atala A. Cell microencapsulation. Adv Exp Med Biol, 2010, 670:126136.

[136] van Zanten J, de Vos P. Regulatory considerations in application of encapsulated cell therapies. Adv Exp Med Biol, 2010, 670:31-37.

[137] Luca G, Galafiore R, Basta G, Ricci M, Calvitti M, Neri L, C N, Becchetti E, Capitani S, Brunetti P, Rossi C. Improved function of rat islets upon co-microencapsulation with Sertoli's cells in alginate/poly-L-ornithine. AAPS PharmSciTech, 2001, 2(3):E15.

[138] Tam SK, Bilodeau S, Dusseault J, Langlois G, Halle JP, Yahia LH. Biocompatibility and physicochemical characteristics of alginate-polycation microcapsules. Acta Biomater, 2011, 7(4):1683-1692.

[139] Moon JS, Jeon HM, Meng W, Akaike T, Kang IK. Morphology and metabolism of hepatocytes microencapsulated with acrylic terpolymer-alginate using gelatin and poly(vinyl alcohol) as extracellular matrices. J Biomater Sci Polym Ed, 2005, 16(10):1245-1259.

[140] Sakai S, Hashimoto I, Tanaka S, Salmons B, Kawakami K. Small agarose microcapsules with cellenclosing hollow core for cell therapy: transplantation of Ifosfamide-activating cells to the mice with preestablished subcutaneous tumor. Cell Transplant, 2009, 18(8):933-939.

[141] Ando T, Yamazoe H, Moriyasu K, Ueda Y, Iwata H. Induction of dopamine-releasing cells from primate embryonic stem cells enclosed in agarose microcapsules. Tissue Eng, 2007, 13(10):2539-2547.

[142] Khademhosseini A, Eng G, Yeh J, Fukuda J, Blumling J, 3rd, Langer R, Burdick JA. Micromolding of photocrosslinkable hyaluronic acid for cell encapsulation and entrapment. J Biomed Mater Res A, 2006, 79(3):522-532.

[143] Kutty JK, Webb K. Vibration stimulates vocal mucosa-like matrix expression by hydrogelencapsulated fibroblasts. J Tissue Eng Regen Med, 2010, 4(1):62-72.

[144] Qi M, Gu Y, Sakata N, Kim D, Shirouzu Y, Yamamoto C, Hiura A, Sumi S, Inoue K. PVA hydrogel sheet macroencapsulation for the bioartificial pancreas. Biomaterials, 2004, 25(27):5885-5892.

[145] Nojehdehian H, Moztarzadeh F, Baharvand H, Mehrjerdi NZ, Nazarian H, Tahriri M. Effect of polyL-lysine coating on retinoic acid-loaded PLGA microspheres in the differentiation of carcinoma stem cells into neural cells. Int J Artif Organs, 2010, 33(10):721-730. 
[146] Mokry J, Karbanova J, Lukas J, Paleckova V, Dvorankova B. Biocompatibility of HEMA copolymers designed for treatment of CNS diseases with polymer-encapsulated cells. Biotechnol Prog, 2000, 16(5):897-904.

[147] Surzyn M, Symes J, Medin JA, Sefton MV. IL-10 secretion increases signal persistence of HEMAMMA-microencapsulated luciferase-modified CHO fibroblasts in mice. Tissue Eng Part A, 2009, 15(1):127-136. 


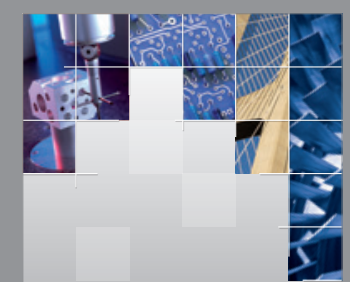

\section{Enfincering}
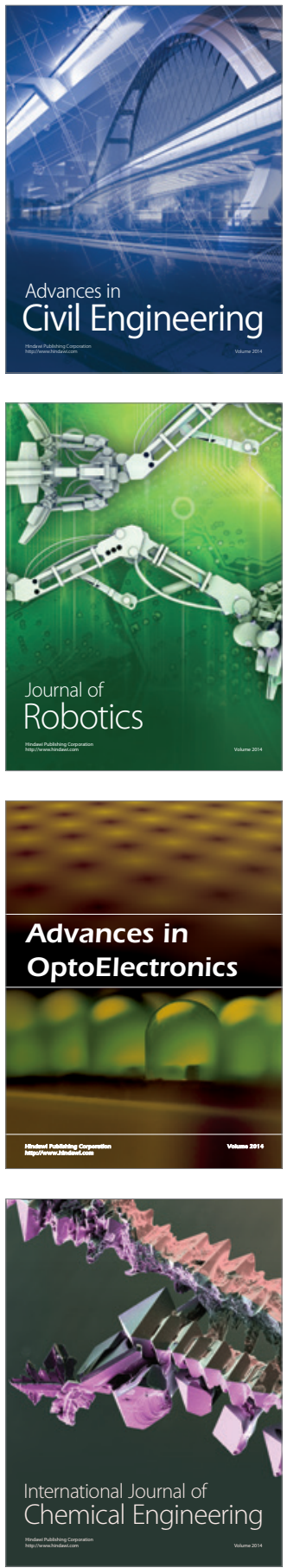

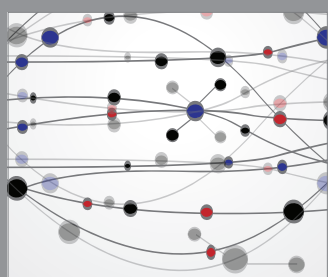

The Scientific World Journal

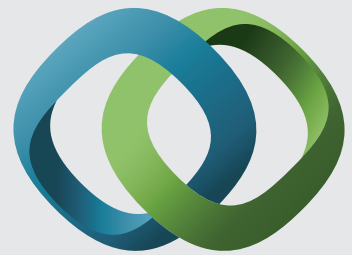

\section{Hindawi}

Submit your manuscripts at

http://www.hindawi.com
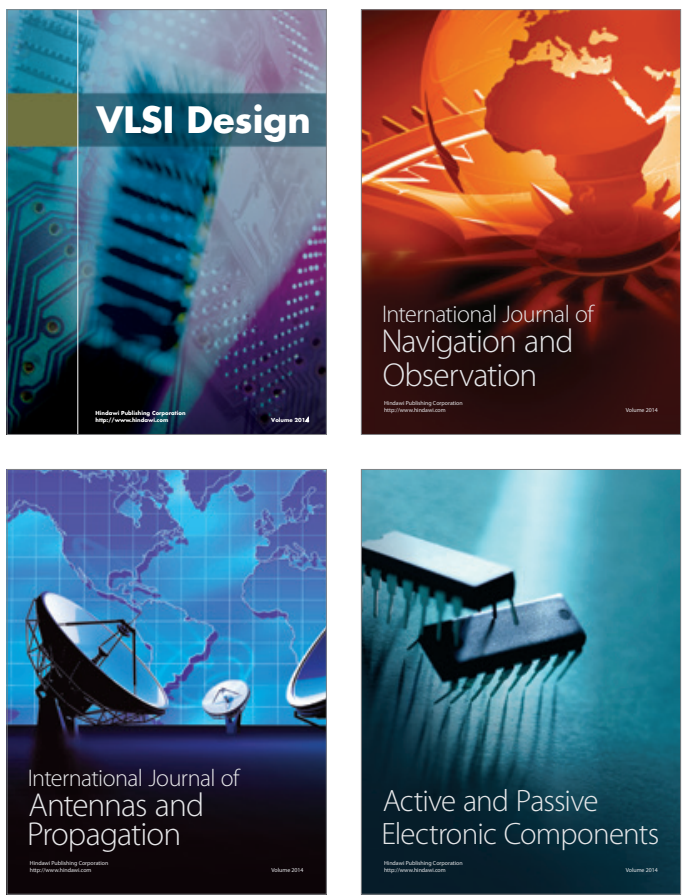
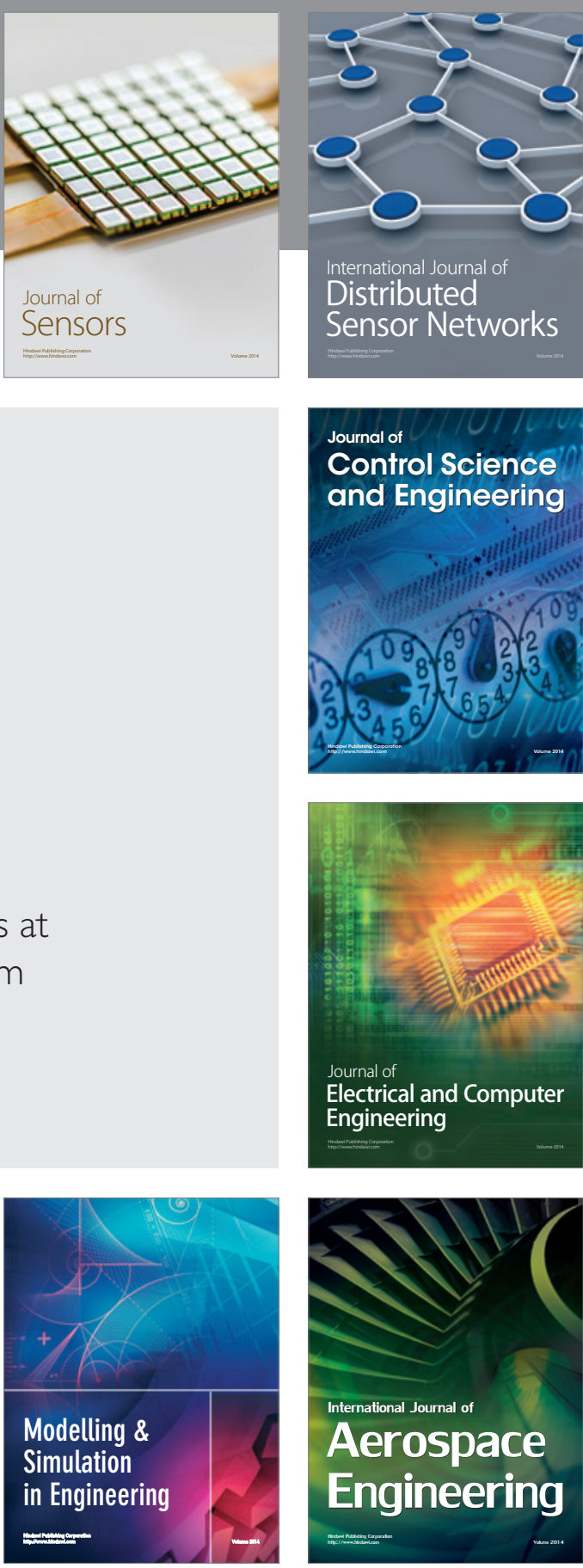

International Journal of

Distributed

Sensor Networks

Journal of

Control Science

and Engineering
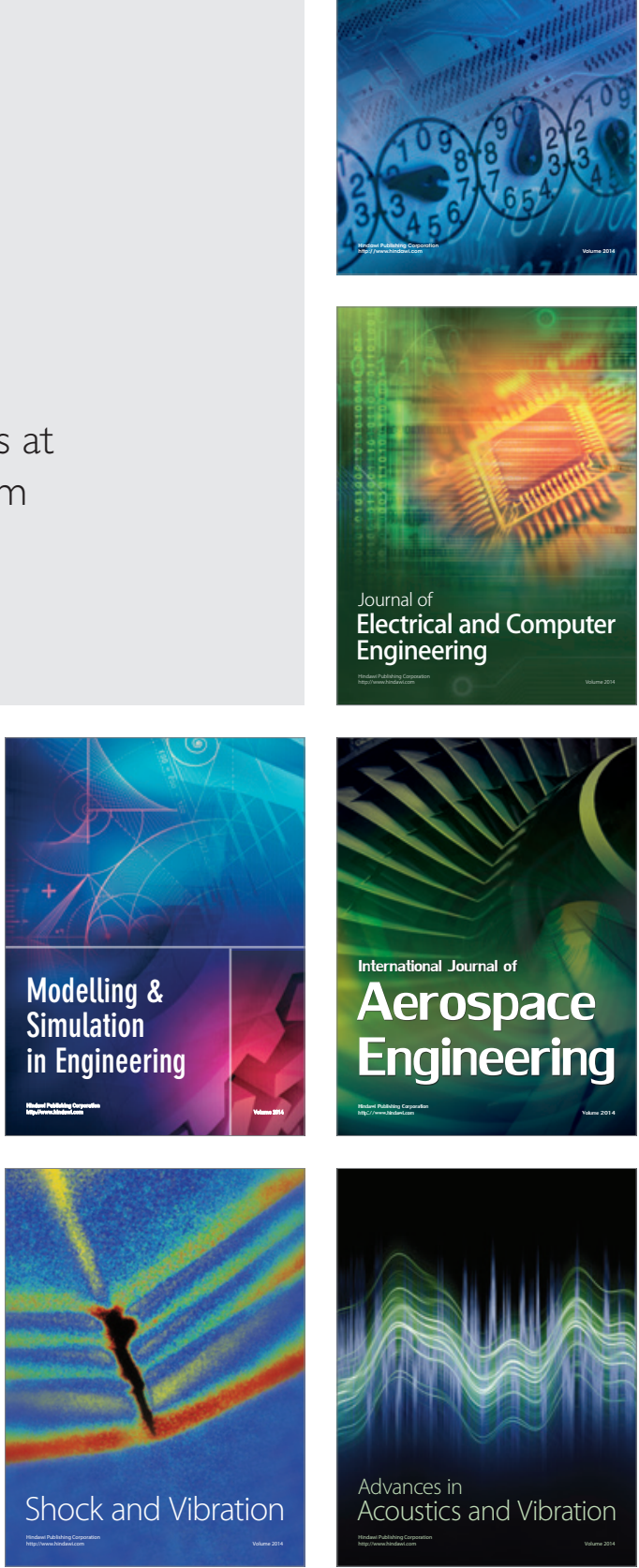